\title{
Response of bread wheat to sulfur and phosphorus fertilizers in the north central Ethiopia
}

\author{
Shawl Assefa ${ }^{1}$, Wassie Haile ${ }^{2^{*}}$ and Wondwosen Tena ${ }^{3}$
}

\begin{abstract}
Background: Emerging research evidences since few years back are indicating that sulfur (S) is becoming a limiting nutrient in some Ethiopian soils. However, these evidences are not sufficient to make a solid conclusion that some soils of Ethiopia have became deficient in $\mathrm{S}$. There is also limited information on the interaction effects of $\mathrm{S}$ and phosphorus (P) on bread wheat in Ethiopia. Therefore, an experiment was conducted to evaluate the effects of $S$ and $P$ fertilizers; and their interaction on yield components and yield of bread wheat grown at Gerba and Deneba locations, Northern central Ethiopia. A factorial experiment consisting of three levels $\left(0,15\right.$ and $\left.30 \mathrm{~kg} \mathrm{ha}^{-1}\right)$ of $\mathrm{S}$ and four levels $\left(0,11,22\right.$ and $\left.44 \mathrm{~kg} \mathrm{ha}^{-1}\right)$ of $\mathrm{P}$ was laid out in RCB design with three replications.

Results: Results revealed that yield components and yield of wheat were significantly affected by both main and interaction effects of S and P fertilizers in both locations. At Gerba, S applied at 15 and $30 \mathrm{~kg} \mathrm{ha}^{-1}$ increased grain yield (GY) of wheat by 32 and $44 \%$ over untreated control treatment, respectively. The corresponding increases at Deneba were 29 and 37\% over untreated control treatment, respectively. However, significantly higher GY was obtained with treatments involving combined application of $S$ and $P$ than that obtained with single application of $S$ or $P$. GY gains due to $S$ and $P$ interaction effect ranged from 46-65 to 52-75\% over untreated control treatment at Gerba and Deneba, respectively. Optimum GY of wheat was obtained with treatment involving $15 \mathrm{~kg} \mathrm{~S} \mathrm{ha}^{-1}+22 \mathrm{~kg} \mathrm{P} \mathrm{ha}^{-1}$.

Conclusion: The results of this experiment revealed that application of $\mathrm{P}$ and $\mathrm{S}$ fertilizer has significantly increased yield component, grain and straw yield of wheat compared to unfertilized control plot, indicating insufficient soil $P$ and $\mathrm{S}$ content for optimum production of wheat and this was confirmed by very low soil test values of $\mathrm{S}$ in both sites. Combined application of S and P produced significantly higher yield of wheat than that obtained with single application of $\mathrm{S}$ or $\mathrm{P}$ indicating synergistic interaction between these nutrients. In all cases, optimum grain and straw yield of wheat was obtained with treatment involving at $22 \mathrm{P}+15 \mathrm{~S} \mathrm{~kg} \mathrm{ha}^{-1}$, while a partial budget analysis result revealed that a combination of $22 \mathrm{P}$ and $15 \mathrm{~S} \mathrm{~kg} \mathrm{ha}{ }^{-1}$ produced the highest MMR (54.9\%). Thus this treatment is found to be economically feasible treatment for bread wheat production in study area of the district.
\end{abstract}

Keywords: Soil fertility decline, Limiting nutrients, Nutrient interaction

*Correspondence: wassiehaile@yahoo.co.uk

${ }^{2}$ College of Agriculture, Hawassa University, P. O. Box 05, Hawassa, Ethiopia

Full list of author information is available at the end of the article

\section{Background}

Bread wheat (Triticum aestivum L.) is one of the most important cereal crops produced and consumed in Ethiopia. It stands third among cereals in terms of area cultivated annually and grain production next to barley and tef [1]. Traditionally, wheat grains are used to prepare household bread, beverage and pancake. 
Despite, its importance and growing demand for bread wheat in Ethiopia, its production and productivity are desperately very low, about $2.5 \mathrm{t} \mathrm{ha}^{-1}$ which is below the world's average of $3.4 \mathrm{t} \mathrm{ha}^{-1}$ [2]. Consequently, the country imports large amounts (30-50\% of total annual demand) wheat grains every year from abroad to meet domestic demand [3] which has grave consequence on foreign currency reserve of the country.

Declining soil fertility is one of the major factors that account for low productivity of wheat in Ethiopia [4, 5]. Declining soil fertility which is caused by soil erosion, continuous cropping of same land year after year, deforestation, inadequate replenishment of nutrients lost through different pathways through application of organic and inorganic fertilizers are the main challenge not only to wheat production but also to the production of all crops $[4,6]$. It is an issue of great concern in Ethiopia as soil nutrient depletion is becoming severe and severe with time since little efforts are being made to reverse the problem. Food security is at the national and global level tends to focus on the supply side of the food equation. The question raised is there enough food available, where food is usually interpreted to mean dietary energy. But availability does not assure access, and enough calories do not assure a healthy and nutritional diet [7]. Among several composite indexes for food security is a large set of proxies for food security [8].

In an effort to overcome declining soil fertility challenge and thereby improve crop productivity including wheat, application of inorganic fertilizer containing nitrogen $(N)$ and phosphorus $(P)$ has long been started in Ethiopia. This is because based on the results of extensive field and laboratory studies some 50 years ago, $N$ and $P$ were identified as the only nutrients deficient in almost all arable lands of Ethiopia despite variations from place to place [9]. Appreciable increases in the yields of several crops used to be obtained due to these inputs [10-12]. However, crop yield gain due to $N$ and $P$ fertilizer application is declining over time despite steady increases in fertilizer consumption in Ethiopia [13]. Declining crop yield responses to $N$ and $P$ fertilizers is attributed to decreasing soil organic matter (SOM) content [13]. Moreover, depletion of other nutrients in addition to $N$ and $P$ could be additional factor for decreasing response of crops to $\mathrm{N}$ and P fertilizers [9]. Sulfur $(S)$ could be one of the most likely limiting nutrients in Ethiopia soils. It is a building block of protein and a key ingredient in the formation of chlorophyll [14]. It has been reported that $S$-deficient plants exhibits reduced plant height and stunted growth, reduced tillers, spikelets and delayed maturity $[15,16]$. Sulfur-deficient plants are shown to be less resistance under stress conditions [17].
In this regards, emerging research evidences are showing that sulfur $(S)$ is one of the nutrients becoming deficient in some Ethiopian soils limiting crop production. For instance, Assefa [18] studied the response of wheat to $S$ application on 18 sites located in Arsi, East Shewa and West Shewa and reported that wheat significantly responded to $S$ fertilizer application in 72\% of experimental sites. He further reported that soils of responding sites had $S$ content below critical level (11-13 $\mathrm{mg} \mathrm{kg}^{-1}$ $\mathrm{SO}_{4}{ }^{-2}-\mathrm{S}$ ) for optimum production of wheat. Similarly, Kiros and Singh [19] studied the effect of sulfur on two varieties of wheat (Enkoy and Shehan) grown in Andisol and Cambisols in semi-arid region of Ethiopia and found that $S$ application significantly increased grain yield, $N$ use efficiency and $S$ uptake of both varieties of wheat. There is little or no information so far on the response of wheat to $\mathrm{S}$ application in Moretena-Jiru district of north Shewa, Ethiopia. Therefore, the designed objective of this experiment was to determine effects of $\mathrm{S}$ and $\mathrm{P}$ application on the growth, yield components and yield of wheat and to determine the economic feasibility of $S$ and $P$ fertilizer application for wheat production in the study district.

\section{Materials and methods \\ Description of the study locations}

The experiment was conducted in 2017/2018 cropping season on two farmers' fields at Gerba and Deneba locations which are $17 \mathrm{~km}$ apart each other and they are found in Moretena-Jiru district of north Shewa, about $195 \mathrm{~km}$ northwest of Addis Ababa. Geographically, the study locations lie between $9^{\circ} 46^{\prime} 53.3^{\prime \prime}-9^{\circ} 52^{\prime} 07.5^{\prime \prime} \mathrm{N}$ and $39^{0} 10^{\prime} 38.1^{\prime \prime}-039^{\circ} 11^{\prime} 28.3^{\prime \prime} \mathrm{E}$. The altitude of the study locations ranges from 2600 to 2700 m.a.s.l with mean annual minimum and maximum temperature ranging from $5.9-11.6{ }^{\circ} \mathrm{C}$ to $17.4-31.2{ }^{\circ} \mathrm{C}$, respectively. The study locations and the district as a whole are characterized by having a uni-modal rainfall pattern and receives an average annual rainfall of $921.2 \mathrm{~mm}$. Vertisols is the dominant soil type occurring in the experimental locations and the district. Major crops grown in the Gerba and Deneba locations; and in Moretena-Jiru district as well include wheat, tef, lentil, faba bean, and chickpea, field pea and grass pea in decreasing orders of area cultivated under these crops.

\section{Soil sampling and analyses}

After selecting the experimental sites, pre-planting soil samples were collected from each site for the analyses of selected physicochemical properties. Composite soil samples were taken from each site from a depth of $0-20 \mathrm{~cm}$ using augur randomly from 15 spots by walking in a zigzag pattern. After thoroughly mixing the 
composite samples, $1 \mathrm{~kg}$ of sub-sample was taken and brought to Debre Birhan agricultural research centre soil laboratory where it was air dried and grounded to pass $2 \mathrm{~mm}$ mesh sized sieve.

The processed samples were analyzed for texture following by Bouyoucos hydrometer method [20]. The $\mathrm{pH}$ of the soil was measured using $\mathrm{pH}$-water method by making soil-to-water suspension of 1:2.5 ratio and was measured using a $\mathrm{pH}$ meter. The soil $\mathrm{OC}$ content was determined by wet digestion method [21]. Total nitrogen (TN) was determined by using the modified microKjeldhal method [22], available P (avaP) was analyzed by using Olsen's calorimetric method as described by Olsen et al. [23], and exchangeable $\mathrm{K}$ in the soil was extracted with $1 \mathrm{~N} \mathrm{NH}_{4} \mathrm{OAc}$ and the amount was estimated using a flame photometer [24]. Soil available sulfur (avaS) was determined turbidimetrically using a spectrophotometer [25]. CEC was measured after saturating the soil with $1 \mathrm{~N}$ $\mathrm{NH}_{4} \mathrm{OAc}$ and displacing it with $1 \mathrm{~N} \mathrm{NaOAc}$ [26].

\section{Treatments, design and experimental procedure}

A factorial experiment consisting of three levels (0, 15 and $\left.30 \mathrm{~kg} \mathrm{ha}^{-1}\right)$ of $S$ and four levels $(0,11,22$ and $44 \mathrm{~kg} \mathrm{ha}^{-1}$ ) of $P$ was laid out in RCB design with three replications. The above $S$ levels of 0,15 and $30 \mathrm{~kg} \mathrm{ha}^{-1}$ were as coded $S O, S 1$ and $S 2$, respectively. Similarly, $P$ levels of $0,11,22$ and $44 \mathrm{~kg} \mathrm{ha}^{-1} P$ were coded as $P 0, P 1$, $P 2$ and $P 3$, respectively. $\mathrm{K}_{2} \mathrm{SO}_{4}$ and TSP were used as $S$ and $P$ sources, respectively. The test crop, wheat variety, Menzaie was sown in a unit plot size of $3.6 \times 3.4 \mathrm{~m}$ with row spacing of $20 \mathrm{~cm}$ apart at a rate of $150 \mathrm{~kg} \mathrm{ha}^{-1}$. The whole doses of $\mathrm{K}_{2} \mathrm{SO}_{4}$ and TSP fertilizers were applied basal applied in both sides of rows just before sowing as per the treatment. To compensate for $K$ applied along with $S$ in $S$ treatment plots, $K$ was applied to all non- $S$ treatment receiving plots in the form of $\mathrm{KCl}$. The recommended dose of $N$ fertilizer for wheat production around the study area which is $167 \mathrm{~kg} \mathrm{ha}^{-1}$ [27] was applied uniformly to all plots in the form of urea. The urea- $\mathrm{N}$ was split applied in which one half of $N$ was applied at planting and the remaining one half was applied one month after planting and first weeding. All agronomic management of the trials was done as per the recommendation for the crop [28].

\section{Data collection and measurements}

Data on plant height (PHT) at harvest, number of fertile tillers per meter square (NFTPM), at harvest, spike length (SPL), number of spikelets per spike (NSPS), number of grains per spike (NGPS), thousand grain weigh (TGW), grain yield (GY), straw yield (SY) and harvest index (HI) data were collected at appropriate stage and time pertinent for each parameter.

\section{Data analysis}

The collected data were subjected to ANOVA. After verifying the homogeneity of error variances, combined analysis of variance was done using the procedure of SAS software version 9.4 [29]. Mean comparisons were done by least significant difference (LSD) at the 5\% level of significance.

\section{Results and discussion}

\section{Soil physicochemical properties}

Pre-planting soil analyses data of selected physicochemical properties of samples collected from experimental location at Geraba and Deneba are summarized in Table 1. The soils of both sites were belonging to clay textural class. Gerba soil has soil reaction near to neutral, whereas the soil of Deneba is slightly alkaline reaction. The SOM and TN content of soils of both locations are in low categories according to Jones [24]. The available $\mathrm{P}$ content of both locations are slightly higher than $6 \mathrm{mg} \mathrm{kg}^{-1}$, lower than the critical soil available $P$ value established for some Ethiopian soils which is $10 \mathrm{mgkg}^{-1}$ [30]. The $S$ content of both soils were also found to be below the critical value of $S$ required for optimum production of wheat which is $10-13 \mathrm{mg} \mathrm{kg}^{-1} \mathrm{SO}_{4}^{-2}-\mathrm{S}$ [31]. The CEC of both soils was also in high category according to rating established by Landon [32].

\section{Effects of sulfur and phosphorus fertilizers on growth of bread wheat}

Main effects of $S$ and $P$ on PHT and NFTPM of wheat in Gerba and Deneba locations are presented in Table 2. S1 and $S 2$ treatments significantly increased PHT of wheat in both locations compared with control (SO), but they were statistically at par with each other. This is in agreement with the findings [33] who reported that application

Table 1 Selected physicochemical properties of soils of experimental sites before planting

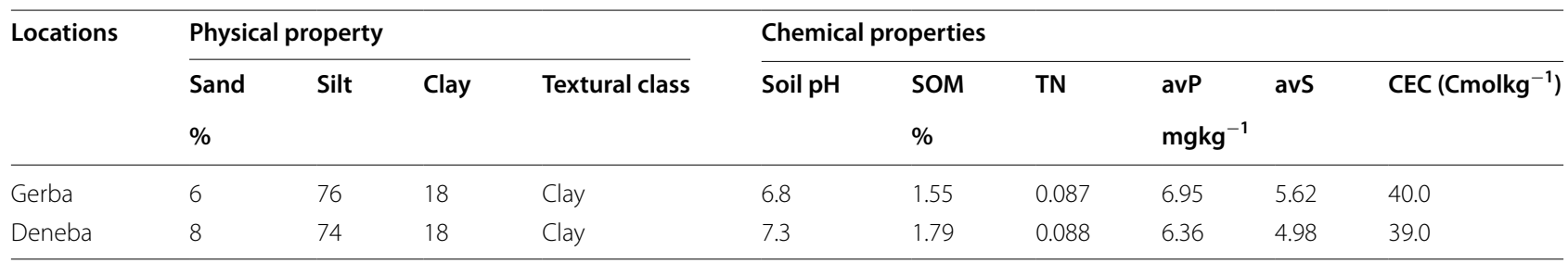


Table 2 Main effects of $S$ and $P$ fertilizers on PHT and NFTPM of wheat at Gerba and Deneba locations

\begin{tabular}{|c|c|c|c|c|}
\hline \multirow[t]{2}{*}{ Treatments } & \multicolumn{2}{|l|}{ Gerba } & \multicolumn{2}{|l|}{ Debeba } \\
\hline & PHT $(\mathrm{cm})$ & NFTPM & PHT $(\mathrm{cm})$ & NFTPM \\
\hline \multicolumn{5}{|l|}{ S-levels } \\
\hline so & $90.3 b^{a}$ & $559.4 \mathrm{C}$ & $88.4 b$ & $496.9 c$ \\
\hline S1 & $93.4 a$ & $607.1 a$ & $92.6 a$ & $536.6 a$ \\
\hline S3 & $94.5 a$ & $583.3 b$ & $92.9 a$ & $519.4 b$ \\
\hline \multicolumn{5}{|l|}{ P-levels } \\
\hline PO & $89.5 c$ & $547.1 \mathrm{C}$ & $88.1 \mathrm{C}$ & $485.8 b$ \\
\hline P1 & $92.4 b$ & $580.9 b$ & $91.2 \mathrm{~b}$ & $522.8 \mathrm{a}$ \\
\hline$P 2$ & $94.2 \mathrm{a}$ & 609.0a & $92.8 a b$ & $538.6 a$ \\
\hline P3 & $94.9 a$ & $594.0 a$ & $93.2 \mathrm{a}$ & $532.2 \mathrm{a}$ \\
\hline$S \times P$ & $* *$ & $* *$ & $* *$ & $* *$ \\
\hline CV (\%) & 1.8 & 3.0 & 2.1 & 5.3 \\
\hline
\end{tabular}

${ }^{a}$ Means within column followed by same letter(s) are not statistically different from each other at 0.05

Probability level, ${ }^{* *}$ significant at 0.01 probability level, ns, non-significant

of $S$ significantly increased PHT of wheat. PHT was also significantly increased by main effects of $P$ application. The highest PHT of was produced by $P 3$ which was statistically at par equal to $P 2$ followed by $P 1$ and the least $\mathrm{PHT}$ was produced by $P O$ in both locations.

NFTPM which are one of the major yield contributing factors [34] were significantly affected by main effects of both $S$ and $P$ fertilizers (Table 2). $S 1$ and $S 2$ increased NFTPM by 8.5 and $4 \%$ over $S O$ in Gerba, respectively. Similarly, in Deneba, $S 1$ and $S 2$ increased NFTPM by 8 and $4.5 \%$ over SO, respectively. In line with this, Assefa [18] reported that application of $S$ significantly increased number of tillers per plant of wheat grown in Keteba and Bekejo sites of east Shewa zone of Ethiopia. According to him, $S$ applied at $10 \mathrm{~kg} \mathrm{ha}^{-1}$ produced the highest number of tillers per plant relative to the control.

Phosphorus has also significantly increased NFTPM in both locations. In Gerba, $P 2$ produced the highest NFTPM followed by $P 3, P 1$ and $P O$ in that order whereas in Deneba, all $P$ rates have significantly produced higher NFTPM relative to $P 0$, but they were statistically at par among each other. The apparent significant increase in NFTPM of wheat in both locations is in agreement with Ibrahim et al. [35] who reported increased in number of fertile tillers in wheat due to increase in $P$ levels over control.

There was also significant interaction effect between $S$ and $P$ on PHT in both locations (Table 3). Significantly higher PHT of wheat was produced treatment involving combined applications of $S$ and $P$ than that obtained with control treatment and treatments with single application of $S$ or $P$ in both locations. The present result is
Table 3 Interaction effects of $S$ and $P$ on PHT and NFTPM of wheat at Gerba and Deneba locations

\begin{tabular}{|c|c|c|c|c|c|}
\hline \multirow[t]{2}{*}{ S levels (kg/ha) } & \multirow{2}{*}{$\begin{array}{l}\text { P levels } \\
\text { (kg/ha) }\end{array}$} & \multicolumn{2}{|l|}{ Gerba } & \multicolumn{2}{|l|}{ Deneba } \\
\hline & & PHT $(\mathrm{cm})$ & NFTPM & PHT (cm) & NFTPM \\
\hline & PO & $84.0 f^{a}$ & $472.2 d$ & $83.1 \mathrm{e}$ & $409.6 c$ \\
\hline \multirow[t]{4}{*}{ so } & P1 & $88.5 \mathrm{e}$ & $567.8 c$ & $88.0 d$ & $513.4 b$ \\
\hline & P2 & $92.8 \mathrm{~cd}$ & $612.8 a b$ & 91.0bcd & $548.5 a$ \\
\hline & P3 & $93.2 \mathrm{bcd}$ & $584.7 \mathrm{bc}$ & $91.6 a b c$ & $516.2 b$ \\
\hline & PO & 91.0de & $590.2 b c$ & $89.8 \mathrm{~cd}$ & $533.1 \mathrm{ab}$ \\
\hline \multirow[t]{4}{*}{ S1 } & $P 1$ & 94.0abc & 595.9abc & $92.1 \mathrm{abc}$ & $526.0 \mathrm{ab}$ \\
\hline & $P 2$ & $94.4 \mathrm{abc}$ & 624.0a & $94.0 \mathrm{ab}$ & $547.1 a$ \\
\hline & P3 & $94.7 a b c$ & $612.8 a b$ & $94.8 \mathrm{a}$ & $540.1 \mathrm{ab}$ \\
\hline & PO & $93.2 \mathrm{bcd}$ & $579.0 \mathrm{c}$ & $91.5 \mathrm{abc}$ & $514.8 b$ \\
\hline \multirow[t]{3}{*}{ S2 } & P1 & $94.8 \mathrm{abc}$ & $579.0 \mathrm{c}$ & $93.5 \mathrm{ab}$ & $528.8 \mathrm{ab}$ \\
\hline & $P 2$ & $95.3 a b$ & $590.3 b c$ & $93.5 \mathrm{ab}$ & $520.4 a$ \\
\hline & P3 & $96.0 \mathrm{a}$ & $584.7 b c$ & $93.3 a b$ & $513.4 a b$ \\
\hline CV (\%) & - & 1.6 & 3.4 & 1.9 & 3.1 \\
\hline
\end{tabular}

${ }^{a}$ Means within column followed by same letter(s) are not statistically different from each other at 0.05 probability level, ns, non-significant

in agreement with Kumar et al. [36] who reported that combined application of $P$ and $S$ produced significantly higher PHT of wheat than that produced by single application either $S$ or $P$. But $S$ by $P$ interaction was not significant for NFTPM of wheat in both locations indicating that change in the levels of $S$ doesn't change the effect of $P$ levels on NFTPM and vice versa.

\section{Effects of sulfur and phosphorus on yield components of wheat}

The main effect results revealed that both $S$ and $P$ fertilizers have significant effect on yield components of wheat grown in Gerba and Deneba locations (Table 4). Both $S 1$ and $S 2$ have significantly increased SPL, and NGPS of wheat relative to $S O$ except SPL at Deneba. However, there was no significant difference between $S 1$ and $S 2$ rates with regards to these parameters of wheat in both sites. Significantly higher NSPS was recorded on $S 2$ on Gerba and $S 1$ on Deneba as compared to S0 but there was no significant difference between $S 1$ and $S 2$. Significantly higher TGW was recorded on $S 1$ than $S O$ and $S 2$ on both locations. In line with this finding, Togay et al. [37] studied the effects of different levels of $S$ on barley in Turkey and found that application of $S$ has significantly increased the above parameters relative to the control. Similarly, all $P$ rates have also significantly increased SPL, NGPS and TGW of wheat in both locations relative to the control $(P O)$ except NSPS at Gerba. But there were no significant differences among $P$ rates with respect to these parameters of wheat indicating that optimum levels of yield components of wheat can be achieved at $P 1$ 
Table 4 Main effects of $S$ and $P$ fertilizers on yield components of wheat at Gerba and Deneba locations

\begin{tabular}{|c|c|c|c|c|c|c|c|c|}
\hline \multirow[t]{2}{*}{ Treatments } & \multicolumn{3}{|l|}{ Gerba } & \multirow[b]{2}{*}{ TWG (g) } & \multicolumn{4}{|l|}{ Deneba } \\
\hline & SPL $(\mathrm{cm})$ & NSPS & NGPS & & $\mathrm{SPL}(\mathrm{cm})$ & NSPS & NGPS & TWG (g) \\
\hline \multicolumn{9}{|l|}{ S-levels } \\
\hline so & $6.05 b^{a}$ & $15.4 b$ & $47.2 b$ & $42.1 \mathrm{~b}$ & 6.20 & $15.4 b$ & $45.2 b$ & $40.8 b$ \\
\hline S1 & $6.50 \mathrm{a}$ & $15.7 a b$ & $48.9 a$ & $43.2 \mathrm{a}$ & 6.05 & $16.0 \mathrm{a}$ & $47.9 a$ & $54.3 a$ \\
\hline S2 & $6.48 a$ & $15.8 \mathrm{a}$ & $48.1 \mathrm{ab}$ & $42.1 \mathrm{~b}$ & 6.03 & $15.7 a b$ & $48.0 \mathrm{a}$ & $40.8 b$ \\
\hline \multicolumn{9}{|l|}{ P-levels } \\
\hline PO & $6.3 b$ & $15.2 b$ & $47.1 \mathrm{~b}$ & $41.8 \mathrm{~b}$ & $5.82 \mathrm{~b}$ & $14.78 b$ & $44.3 b$ & $41.4 b$ \\
\hline P1 & $6.5 a$ & $15.8 \mathrm{~b}$ & $48.2 \mathrm{ab}$ & 42.3ab & $6.01 \mathrm{ab}$ & $15.8 \mathrm{a}$ & $47.3 a$ & $45.2 \mathrm{a}$ \\
\hline$P 2$ & $6.7 a$ & $15.8 \mathrm{~b}$ & $48.9 a$ & $42.9 a$ & $6.26 a$ & $16.2 \mathrm{a}$ & $48.3 a$ & $44.9 a$ \\
\hline P3 & $6.7 a$ & $15.7 a$ & $48.1 a b$ & $42.5 \mathrm{ab}$ & $6.21 a$ & $16.0 \mathrm{a}$ & $48.4 a$ & $40.3 b$ \\
\hline$S \times P$ & ns & ns & ns & $* *$ & ns & ns & ns & $* *$ \\
\hline CV (\%) & 3.4 & 2.8 & 3.8 & 2.1 & 3.5 & 3.2 & 4.6 & 5.8 \\
\hline
\end{tabular}

${ }^{a}$ Means within column followed by same letter(s) are not statistically different from each other at 0.05 probability level, ${ }^{* *}$ significant at 0.01 probability levels, ns, nonsignificant

rate in both sites. In soils with low available $P$ contents such as at Gerba and Deneba locations in this case, application of $P$ significantly increases yields of crops including wheat through its positive impacts on the growth and yield components of crops [38].

The interaction effects of $S$ and $P$ were non-significant on SPL, NSPS, NGPS in both locations suggesting that the change in the levels of $S$ was not affected by the change in the levels of $P$ with respect to these parameters and vice versa. However, there was a significant interaction effect between $S$ and $P$ on TGW in both locations (Fig. 1). The result implies that the effect of changing levels of $S$ on TGW was significantly changed with a change in the levels of $P$ and vice versa. In both locations significantly higher TGW of wheat was obtained with treatment involving combined applications of $S$ and $P$ and the highest TGW was obtained with treatment involving $S+P$ applied at 15 and $22 \mathrm{~kg} \mathrm{ha}^{-1}$, respectively, in both locations.

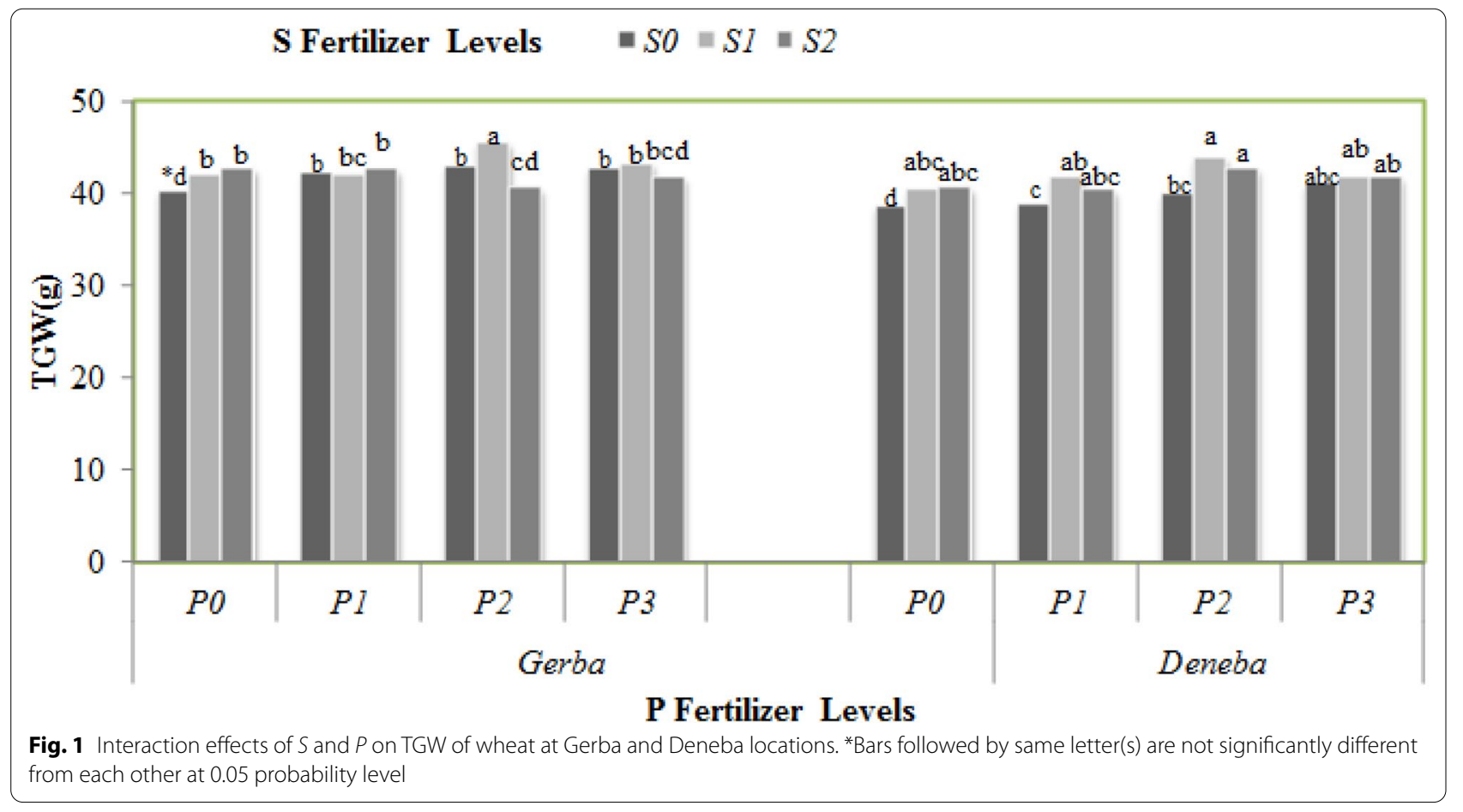




\section{Effects of sulfur and phosphorus on yield of wheat}

Both grain yield (GY) and straw yield (SY) of wheat were significantly affected by main effects of $S$ application in both Gerba and Deneba locations (Table 5). At Gerba, $S 1$ and $S 2$ treatments have significantly increased GY by 13 and $12 \%$ over the control (SO), respectively, and SY by 39 and $38 \%$ over SO, respectively. Similarly, at Deneba, $S 1$ and $S 2$ rates have significantly increased GY by 19 and $20 \%$ over SO, respectively and same treatments increased SY by 24 and $26 \%$ over SO, respectively. The apparent significant response of wheat to $S$ application in both locations found in this study indicates low level soil $S$ for optimum production of wheat in the study areas. This is substantiated by low level or below critical soil test $S$ values (Table 1) in both soils for optimum crop production. These results are in agreement with the finding of Assefa [18] Who studied the response of wheat to $S$ application on 18 sites located in Arsi, east Shewa and west Shewa and reported that wheat significantly responded to $S$ fertilizer application in $72 \%$ of experimental sites. He further reported that soils of responding sites had $S$ content below critical level (10-13 $\left.\mathrm{mg} \mathrm{kg}^{-1} \mathrm{SO}_{4}{ }^{-2}-\mathrm{S}\right)$ for optimum production of wheat. In another study by Khan et al. [39] reported that $S$ applied at $20 \mathrm{~kg} \mathrm{ha}^{-1}$ at stem elongation stage significantly increased GY of wheat in Peshawar, Pakistan by $28.5 \%$ over untreated control. According to DeRuiter and Martin [40], wheat yield can be increased by up to $42 \%$ due to $S$ fertilizer depending on the inherent $S$ level in a particular soil. The further noted that usually best crop response to $S$ is obtained at application rates between 10 and $20 \mathrm{~kg} \mathrm{ha}^{-1}$, even though much higher application rates $S\left(49-60 \mathrm{~kg} \mathrm{ha}^{-1}\right)$ have been reported in highly calcareous soils in India [41]. The main effect of S application on HI was significant at
Gerba but not at Deneba locations (Table 5). At Gerba, both levels of $S$ have significantly increased HI relative to the control but they were statistically at par with each other. This is in line with the finding of Togay et al. [37] who reported that application of $S$ significantly increased $\mathrm{HI}$ in barley.

GY and SY of wheat were also significantly affected by main effect of $P$ application in both locations (Table 5). All $P$ levels produced significantly higher GY and SY compared to control in both sites. The GY and SY increasing effects of $P$ levels were in the order of $P 3=P 2>P 1>P O$. This suggests that the soil of the study sites is low in their available $P$ content for optimum growth and productivity of wheat. This was substantiated by low level soil test $P$ values of both sites shown in Table 1 . This is in line with reports of several researchers that $P$ is the second most limiting nutrients in almost all arable soils of Ethiopian $[4,9,30]$.

The interaction effects of $S$ and $P$ on GY and SY of wheat are shown in Fig. 2. The grain yields as influenced by different levels of $\mathrm{P}$ and $\mathrm{S}$ are presented in Fig. 2. The addition of $22 \mathrm{~kg} \mathrm{P} \mathrm{ha}^{-1}$ with $15 \mathrm{~kg} \mathrm{~S}^{-1}$ produced maximum grains yield $\left(3526.8 \mathrm{~kg} \mathrm{ha}^{-1}\right)$ which was significantly different from other treatment combination except $22 \mathrm{P}+30 \mathrm{~S}, 44 \mathrm{P}+15 \mathrm{~S}$ and $44 \mathrm{P}+30 \mathrm{~S} \mathrm{~kg} \mathrm{ha}^{-1}$. This treatment has a yield advantage of $40.1 \%$ over control treatment. However, grain yield become decreased numerically but not significantly as interactive application rate of $\mathrm{P}$ and $\mathrm{S}$ beyond $22 \mathrm{P}$ and $15 \mathrm{~S} \mathrm{~kg} \mathrm{ha}^{-1}$. The minimum grain yield $\left(2076.7 \mathrm{~kg} \mathrm{ha}^{-1}\right)$ was recorded in control plot (untreated with $\mathrm{P}$ and S) shown in Fig. 2. Even though, the overall grain yield of the wheat was lower compared to potential yield of wheat, the treatment combinations showed that $\mathrm{P}$ and $\mathrm{S}$ at the rate of 22 and

Table 5 Main effects of $S$ and $P$ fertilizers on yield $\left(\mathrm{tha}^{-1}\right)$ of wheat at Gerba and Deneba locations

\begin{tabular}{|c|c|c|c|c|c|c|}
\hline \multirow[t]{2}{*}{ Treatments } & \multicolumn{3}{|l|}{ Gerba } & \multicolumn{3}{|c|}{ Deneba } \\
\hline & GY & SY & $\mathrm{HI}$ & GY & SY & $\mathrm{HI}$ \\
\hline \multicolumn{7}{|l|}{ S-levels } \\
\hline so & $3.41 b^{a}$ & $4.27 \mathrm{~b}$ & $0.40 \mathrm{~b}$ & $3.13 b$ & $3.84 b$ & 0.43 \\
\hline S1 & $3.85 a$ & $5.89 a$ & $0.44 a$ & $3.71 a$ & $4.76 a$ & 0.44 \\
\hline S3 & $3.83 a$ & $5.85 \mathrm{a}$ & $0.45 a$ & $3.75 \mathrm{a}$ & $4.83 a$ & 0.44 \\
\hline \multicolumn{7}{|l|}{ P-levels } \\
\hline PO & $3.17 \mathrm{c}$ & $4.37 c$ & $0.40 \mathrm{~b}$ & $2.88 c$ & $3.38 \mathrm{c}$ & 0.42 \\
\hline P1 & $3.72 b$ & $5.10 \mathrm{~b}$ & $0.42 \mathrm{a}$ & $3.59 b$ & $4.61 b$ & 0.44 \\
\hline$P 2$ & $3.93 a$ & $5.92 \mathrm{a}$ & $0.42 \mathrm{a}$ & $3.83 a$ & $4.87 a b$ & 0.44 \\
\hline P3 & $3.97 a$ & $5.97 a$ & $0.41 b$ & $3.80 a$ & $5.07 a$ & 0.43 \\
\hline$S \times P$ & $* *$ & $* *$ & ns & $* *$ & $* *$ & ns \\
\hline CV (\%) & 4.2 & 4.1 & 3.25 & 4.8 & 7.7 & 5.1 \\
\hline
\end{tabular}

${ }^{a}$ Means within column followed by same letter(s) are not statistically different from each other at 0.05 probability level, **significant at 0.01 probability level, ns, nonsignificant 


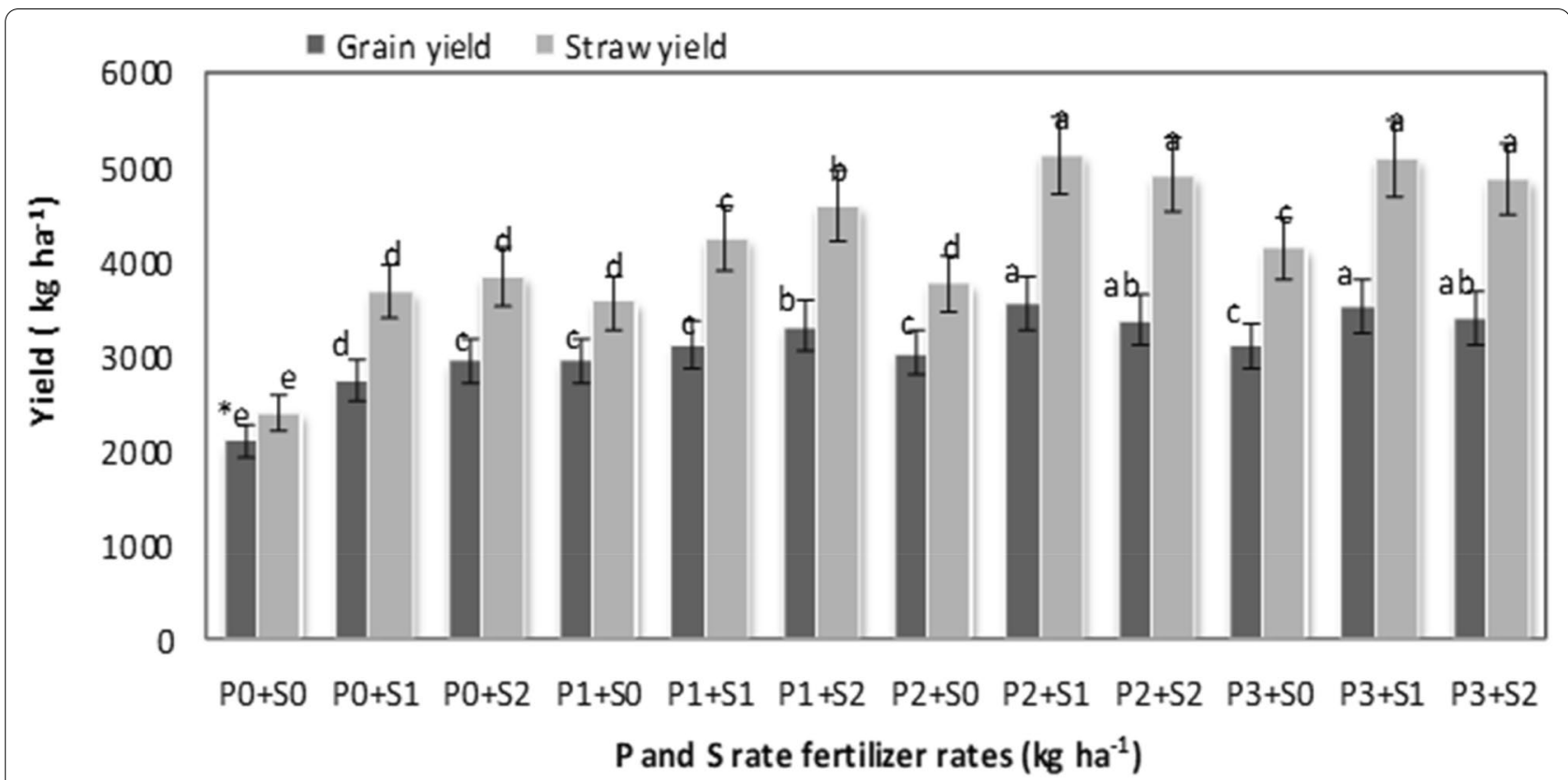

Fig. 2 Interaction effects of $\mathrm{P}$ and $\mathrm{S}$, on yield of wheat grown at Gerba and Deneba locations. *Bars followed by same letter(s) are not statistically different from each other at 0.05 probability level

$15 \mathrm{~kg} \mathrm{ha}^{-1}$, respectively, was an advantageous. The straw yield of wheat was also influenced significantly $(\mathrm{P} \leq 0.01)$ by different levels of $\mathrm{P}$ and $\mathrm{S}$ application interactively. The higher straw yield $\left(5120.0 \mathrm{~kg} \mathrm{ha}^{-1}\right)$ was produced when

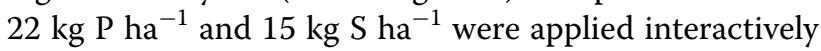
(Fig. 2) which have straw yield boosted by $53.4 \%$ over control treatment. Similar trends were also observed like grain yield due to the influence of different $\mathrm{P}$ and $\mathrm{S}$ application rates. The minimum straw yield $\left(2385.6 \mathrm{~kg} \mathrm{ha}^{-1}\right)$ was recorded in control plot.

In agreement with the current finding, both synergistic and antagonistic interactions between $S$ and $P$ have been reported in literature [42-44]. For instance, Uddin et al. [45] reported that there was a synergistic interaction between $S$ and $P$ combined applied at 20 and $40 \mathrm{~kg} \mathrm{ha}^{-1}$, respectively, on yield of rice grown in Joydebpur, Bangladesh. According to these authors, the above treatment increased GY and SY of rice by 61 and 33\% over the control, respectively. But combined application of $S$ and $P$ above these rates resulted in antagonistic interaction effect on rice as was revealed by declining yield response. Similarly, Islam et al. [46] reported synergistic effect of these nutrients on chickpea when $15 \mathrm{~kg} \mathrm{ha}^{-1} S$ was combined applied with $40 \mathrm{~kg} \mathrm{ha}^{-1} P$. But they found antagonistic effect when $30 \mathrm{~kg} \mathrm{ha}^{-1} S$ was combined applied with $80 \mathrm{~kg} \mathrm{ha}^{-1} P$.

The synergistic interaction effect of $S$ and $P$ that occurs at specific combinations levels of these nutrients on crops including wheat could be attributed to increased uptake and utilizations of soil nutrients due to welldeveloped roots and shoots [47]. On the contrary, antagonistic interaction effect between $S$ and $P$ that may occur at higher dose of $S$ when it is combined applied with $P$ or vice versa could be attributed to competition between the two nutrients for uptake sites on plant roots as both nutrients are taken by roots as negatively charred ions $\left(\mathrm{H}_{2} \mathrm{PO}_{4}{ }^{1-} / \mathrm{HPO}_{4}{ }^{2-}-\mathrm{P}\right.$ and $\left.\mathrm{SO}_{4}{ }^{2-}-\mathrm{S}\right)$. This is substantiated by the finding of Muhammad et al. [47] who reported that application of high dose of $\mathrm{S}\left(75 \mathrm{~kg} \mathrm{ha}^{-1}\right)$ resulted in decreased uptake of $P$ by maize plant and vice versa ultimately resulted in decrease grain yield. In general, the interaction between $S$ and $P$ could be synergistic or antagonistic depending on the initial soil fertility status, the amounts of nutrient applied and types of crop [48]. The current result has similar trend with Islam [35] reported that application of $S$ and $P$ at higher rate $(40 \mathrm{~kg}$ $\mathrm{S}$ and $35.2 \mathrm{~kg} \mathrm{P} \mathrm{ha}^{-1}$ ) showed reduction in yields. Other findings [49] revealed that combined application of $\mathrm{P}$ and $\mathrm{S}$ at $50 \mathrm{~kg} \mathrm{P}_{2} \mathrm{O}_{5}$ and $20 \mathrm{~kg} \mathrm{~S}^{-1}$ improve yield of wheat over control. Similarly, the interaction of $\mathrm{P}$ and $\mathrm{S}$ levels increased their beneficial synergistic effect and applying of the individual Sulfur levels with P level produced increases in the grain yield of wheat over the control [50].

\section{Partial budget analysis}

The data related to partial budget analysis are given in Table 6. It is clear from the data that maximum net benefit (45351.7 ET Birr) was obtained from combined 
Table 6 Marginal analysis of the non-dominated treatment

\begin{tabular}{lllllllllrr}
\hline Treatment & Adj. GY & Adj. STY & GBGY & GBSTY & TVC & TGB & NB & MC & MB & MRR \\
\hline SOP11 & 2941.5 & 3554.9 & 30885.9 & 8282.8 & 2120.2 & 39168.7 & 37048.5 & 453.6 & 11351.1 & 25.0 \\
SOP22 & 3016.0 & 3754.7 & 31667.7 & 8748.5 & 2573.7 & 40416.1 & 37842.4 & 453.6 & 793.9 & 1.8 \\
S15P11 & 3094.8 & 4233.5 & 32495.0 & 9864.1 & 3148.0 & 42359.1 & 39211.1 & 441.6 & 4783.7 & 10.8 \\
S15P22 & 3526.8 & 5120.0 & 37031.6 & 11929.5 & 3609.4 & 48961.2 & 45351.7 & 124.7 & 6850.3 & 54.9
\end{tabular}

${ }^{a}$ Adj.GY, adjusted grain yield ( $\mathrm{kg} \mathrm{ha}^{-1}$ ); Adj. STY, adjusted straw yield ( $\mathrm{kg} \mathrm{ha}^{-1}$ ); TGB, total growth benefit; TVC, total variable cost; NB, net benefit; $M C$, marginal cost; $\mathrm{MB}$, marginal benefit; MRR, marginal rate of return; $\mathrm{PO}, 0 \mathrm{~kg} \mathrm{ha}^{-1} \mathrm{P} ; \mathrm{P} 11, \mathrm{~kg} \mathrm{ha}^{-1} 11 \mathrm{P} ; \mathrm{P} 22,22 \mathrm{~kg} \mathrm{ha}^{-1} \mathrm{P} ; \mathrm{P} 44,44 \mathrm{~kg} \mathrm{ha}^{-1}$ phosphorus; SO, $0 \mathrm{~kg} \mathrm{Sha}^{-1} ; \mathrm{S} 15,15 \mathrm{~kg} \mathrm{Sha}^{-1}$; $\mathrm{S} 30,30 \mathrm{~kg} \mathrm{Sha}^{-1}$.

application of $\mathrm{S}$ and $\mathrm{P}$ at the rate of $15 \mathrm{~kg} \mathrm{~S}$ and $22 \mathrm{~kg}$ $\mathrm{P} \mathrm{ha}^{-1}$ and followed by rate of $15 \mathrm{~kg} \mathrm{~S}$ and $44 \mathrm{~kg} \mathrm{P} \mathrm{ha}^{-1}$ (44128.3 ET Birr.). Minimum net benefit (25697.4 ET Birr.) was recorded in control (treatment that did not receive any $\mathrm{S}$ and $\mathrm{P}$ fertilizers).

Depend on dominancy analysis, treatments of $\mathrm{S}$ and $\mathrm{P}$ at $15 \mathrm{~kg} \mathrm{~S}$ without $\mathrm{P}, 44 \mathrm{~kg} \mathrm{P}$ without $\mathrm{S}, 30 \mathrm{~kg} \mathrm{~S}$ without P, $30 \mathrm{~kg} \mathrm{~S}$ with $22 \mathrm{~kg}$ P, $15 \mathrm{~kg}$ S with $44 \mathrm{~kg}$ P, $30 \mathrm{~kg} \mathrm{~S}$ with $44 \mathrm{~kg} \mathrm{P}, 30 \mathrm{~kg} \mathrm{~S}$ with $11 \mathrm{~kg} \mathrm{P} \mathrm{ha}^{-1}$ and control were dominated by the rest four treatments and they were also excluded from further economic analysis. The data regarding the marginal rate of return (MRR) revealed that maximum MRR (5490\%) was obtained when S and P were applied at the combined rate of $15 \mathrm{~kg} \mathrm{~S}$ and $22 \mathrm{~kg} P$ $\mathrm{ha}^{-1}$ followed by rate of $11 \mathrm{~kg} \mathrm{P} \mathrm{ha}^{-1}$ without $\mathrm{S}(2502 \%)$. Minimum MRR was (175\%) recorded in treatment where application of $\mathrm{P}$ at $22 \mathrm{~kg} \mathrm{ha}^{-1}$ without $\mathrm{S}$.

Data from Table 6 clearly revealed that the non-dominated treatments associated with MRR are greater than $100 \%$. This implies that the four non-dominated treatments are economically feasible alternative to the other dominated treatments. MRR, $5490 \%$ means the producer obtained an additional income of 54.9 Ethiopian birr per a unite cost they have invested. Generally, treatment combination of $\mathrm{S}$ and $\mathrm{P}$ at $15 \mathrm{~kg} \mathrm{~S}$ and $22 \mathrm{~kg} \mathrm{P} \mathrm{ha}^{-1}$ gave better MRR value relative to the other four non-dominated treatments and profitability can be optimized by using this treatment.

\section{Conclusion}

The results of this experiment revealed that application of $\mathrm{P}$ and $\mathrm{S}$ fertilizer has significantly increased yield component, grain and straw yield of wheat compared to unfertilized control plot, indicating insufficient soil $\mathrm{P}$ and $\mathrm{S}$ content for optimum production of wheat and this was confirmed by very low soil test values of $S$ in both sites. Combined application of $\mathrm{S}$ and $\mathrm{P}$ produced significantly higher yield of wheat than that obtained with single application of S or P indicating synergistic interaction between these nutrients. But this was true for treatments involving combined applications low level of $S$ and increasing levels of $\mathrm{P}$ or vice versa. Otherwise, there was decreasing trend of yield gains with treatments involving combined applications at higher levels of both nutrients. In all cases, optimum grain and straw yield of wheat was obtained with treatment involving at $22 \mathrm{P}+15 \mathrm{~S} \mathrm{~kg} \mathrm{ha}^{-1}$. While, partial budget analysis result revealed that, combination of $22 \mathrm{P}$ and $15 \mathrm{~S} \mathrm{~kg} \mathrm{ha}{ }^{-1}$ produced the highest MMR (54.9\%) and thus, this treatment is found to be economically feasible treatment for bread wheat production in study area of the district.

\section{Abbreviations \\ avP: Available phosphorus; avS: Available sulfur; CV: Coefficient of variation; $\mathrm{HI}$ : Harvest index; N: Nitrogen; NFTPM: Number of fertile tillers per meter square: NGPS: Number of grains per spike; NSPS: Number of spikelets per spike; SPL: Spike length; GY: Grain yield; P: Phosphorus; S: Sulfur; SY: Straw yield; TGW :Thousand grain weight; PHT: Plant height; Adj.GY: Adjusted grain yield (kg $\mathrm{ha}^{-1}$ ); Adj. STY: Adjusted Straw yield $\left(\mathrm{kg} \mathrm{ha}^{-1}\right)$; TGB: Total growth benefit; TVC: Total variable cost; NB: Net benefit; MC: Marginal cost; MB: Marginal benefit; MRR: Marginal rate of return.}

\section{Acknowledgements}

The senior author of this manuscript would like extend his thanks to Ato Lisanu Getaneh and Ato Getaneh Shegaw, technicians in the soil laboratory of Debre Berhan agricultural research center for their great support in analyzing soil sample.

\section{Authors' contributions}

SAA generated the research idea, drafted into proposal containing details of background information, objectives, treatments, experimental design, etc. After defending his proposal and getting approval, he conducted the field and laboratory experiments, collected all the necessary data, analyzed the data and wrote his thesis. WHW served as major supervisor of SAA and played a role in guiding the research starting from shaping the proposal up to reviewing and edition the draft thesis of SAA. WTB was CO-supervisor of SAA and involved in commenting and reviewing the draft thesis of SAA. This manuscript was extracted from the thesis of SAA. All authors read and approved the final manuscript.

\section{Funding}

This study was financed by Amhara region agricultural research Institute and we are very grateful to it.

\section{Availability of data and materials}

All relevant data generated from the study and reported in the manuscript are included in this article. Further data sets are available from the senior and/or corresponding author upon request.

\section{Declarations}

Ethics approval and consent to participate Not applicable. 


\section{Consent for publication \\ Not applicable.}

\section{Competing interests}

The authors declare that they have no competing interests.

\section{Author details}

${ }^{1}$ Amhara Agricultural Research Institute, Debre Berhan Agricultural Research Center, P. O. Box 112, Debre Berhan, Ethiopia. ${ }^{2}$ College of Agriculture, Hawassa University, P. O. Box 05, Hawassa, Ethiopia. ${ }^{3}$ College of Agriculture and Natural Science, Debre Berhan University, P. O. Box 445, Debre Berhan, Ethiopia.

\section{Received: 20 January 2020 Accepted: 3 May 2021}

\section{Published online: 05 October 2021}

\section{References}

1. CSA (Central Statistical Agency). Agricultural sample survey $2015 / 2016$ (2008 EC) Agricultural sample survey. Volume I: report on area and production of major crops (private peasant holdings, Meher season). Statistical Bulletin 584, Addis Ababa; 2016.

2. FAOSTAT. Online http://faostat.fao.org/site/291/default.aspx. Published 2016. Accessed 6 Mar 2017.

3. Minot N, Warner JS, Lemma S, Kassa L, Gashaw A, Rashid S. The Wheat supply chain in Ethiopia: patterns, trends, and policy options. International Food Policy Research Institute (IFPRI), Addis Ababa, Ethiopia; 2015.

4. Birhan A, Sofiya K, Temesgen D, Kassu T, Mihreteab H. Soil fertility management studies on wheat in Ethiopia: a review. Eth $J$ Nat Res. 2016;16:1-23.

5. Tamene L; Amede T; Kihara J; Tibebe D; Schulz S. (eds.). A review of soil fertility management and crop response to fertilizer application in Ethiopia: towards development of site- and context-specific fertilizer recommendation. CIAT Publication No. 443. International Center for Tropical Agriculture (CIAT), Addis Ababa, Ethiopia. 2017; p. 86 http://hdl.handle. net/10568/82996

6. van Beek CL, Elias E, Yihenew GS, Heesmans H, Tsegaye A, Feyisa H, Tolla M, Melmuye M, Gebremeskel Y, Mengist S. Soil nutrient balances under diverse agro- ecological settings in Ethiopia. Nutri Cycl Agroeco. 2016. https://doi.org/10.1007/s10705-016-9803-0.

7. Pinstrup-Andersen P. Food security: definition and measurement. Food security. 2009;1(1):5-7.

8. Santeramo FG. On the composite indicators for food security: Decisions matter! Food Rev Intl. 2015;31(1):63-73.

9. Wassie $H$, Tekalign M. The effect of potassium on the yields of potato and wheat grown on the acidic soils of Chencha and HagereSelam in Southern Ethiopia. International Potash Institute, e-ifc 2013, No. 35. http://www. ipipotash.org/en/k-center/e-ifc-newsletter.

10. Kelsa K, Tadesse Y, Tesfa B. Influence of fertilizer and its related management practice on maize grain yield in major maize producing areas of Ethiopia. Proceedings of the first national maize workshop of IAR and CIMMYT, Addis Ababa; 1992

11. Gebreyes $\mathrm{G}$. Soil fertility characterization and response of durum wheat to nitrogen and phosphorus fertilization on vertisols at Enewari, Northeastern Ethiopia. M.Sc. Thesis. Haramaya University, Ethiopia; 2008.

12. IFPRI. Fertilizers in Ethiopia: policies, value chains and profitability. IFPRI, Washington DC: 2012

13. IFPRI. Fertilizers and soil fertility potential in Ethiopia: Constraint and opportunities for enhancing the system. IFPRI, Washington DC; 2010.

14. Duke $S$, Reisenauer $H$. Roles and requirements of sulfur in plant nutrition. Sulfur in agriculture. In: Tabatabai MA (Ed.). Agronomy Monograph No. 27, ASA, Madison; 1986

15. Aulakh M, Chhibba I. Sulfur in soils and response of crops to its application in Punjab. Pakistan Fert News. 1992;37:33-5.

16. Kumar R, Singh VK, Sharma RP, Kumar A, Singh G. Impact of nitrogen, phosphorus, potash and sulphur on productivity of rice-wheat system in sub-humid region. J Agric Phys. 2012;12:84-8.

17. Dobermann A, Fairhurst T. Nutrient disorder and nutrient management. Handbook Series. Potash and Phosphate Institute of Canada and IRRI; 2000
18. Assefa M. Sulphur status of soils and wheat plants in three representative areas of the central highlands of Ethiopia. PhD. Dissertation, University of agriculture. Morogoro, Tanzania; 2016.

19. Kiros $H$, Singh BR. Response of wheat cultivars to $N$ and $S$ for crop yield, nitrogen use efficiency and protein quality in the semiarid region. J Plant Nutri. 2009;32:1768-87.

20. Bouyoucos G. Hydrometer method improved for making particle size analysis of soils. Agron J. 1962;54:464-5.

21. Walkley A, Black I. An examination of Degtjareff method for determining soil organic matter and a proposed modification of the chromic acid titration method. Soil Scie. 1934;37:29-37.

22. Cottenie A. Soil and plant testing as a basis of fertilizer recommendations. FAO soil bulletin 38/2. Food and Agriculture Organization of the United Nations, Rome; 1980

23. Olsen SR, Cole CV, Watanabe FS, Dean LA. Estimation of available phosphorus in soils by extraction with sodium carbonate. USDA Circular. 1954;939:1-19

24. Jones BJJ. Laboratory guides for conducting soil tests and plant analysis. London: CRC Press; 2001.

25. Singh P, Garg A, Raman M, Agrawal D. Effect of replacing barley grain with wheat bran on intake and utilization of nutrients in adult sheep. Small Ruminant Res. 1999:31(3):215-9.

26. Chapman HD. Cation exchange capacity by ammonium saturation. pp 891-901. In: Black CA, Ensminger LE, Clark FE (eds.) Method of soil analysis. ASA, Madison; 1965

27. Adamu M. Response of wheat to NP fertilizer rates, precursor crops and types of vertisols in central highlands of Ethiopia. J Agric Scie. 2018;10(4):1-14.

28. EIAR (Ethiopian Institute of Agricultural Research). Crop production technologies and their application, Ethiopian Institute of Agricultural Research (EIAR), Addis Ababa: 2007

29. SAS. User's guide, statistics, version 9.4 Edn. SAS Inst, Inc., Cary, NC; 2012

30. Tekalign M, Haque I. Phosphorus status of some Ethiopian soils. III: Evaluation of soil test methods for available phosphorus. Tropical Agric. 1991:68:51-6.

31. Tandon HLS. Sulphur research and agricultural production in India. 3rd edn. The Sulphur Institute, Washington DC, USA; 1991.

32. Landon JR. Booker tropical soil manual: a handbook for soil survey and agricultural land evaluation in the tropics and subtropics. Abingdon: Routledge; 2014.

33. Chaudhary PD, Jat RS, Sharma HS. Interaction effect of phosphorus, sulphur and PSB inoculation on growth, yield and nutrient uptake of wheat. Anna Agric Res. 2003;24(1):12-6.

34. Hakoomat A, Naeem S, Shakeel A, Ahmad W, Ahmad N. Response of wheat crop to phosphorus fertilizers and application methods grown under agro-climatic conditions of southern Punjab. Pakistan J Agric Scie. 2012:49(4):485-9.

35. Ibrahim M, Ullah $\mathrm{H}$, Ahmad B. Effect of incremental dose of phosphorous and sulphur upon yield and protein content of wheat. Biol Div Cons. 2012;5(3):76-81.

36. Kumar S, Ghanshyam S, Rajeev K, Pradeep K, Brij M. Effect of phosphorus, sulphur and zinc on growth, yield and yield attributes of wheat (Triticum aestivum L). Int J Current Microbiol Applied Scie. 2017;6(8):2581-4.

37. Togay Y, Togay N, Cig F, Erman M, Celen AE. The effect of sulphur applications on nutrient composition, yield and some yield components of barley (Hordeum vulgare L). Afric J Biotech. 2008;7:3255-60.

38. Getachew A. Response of barley to nitrogen and phosphorus application in Wello highlands of Ethiopia. Eth J Nat Res. 2001;3(1):19-38.

39. Khan RM, Hussain SZ, Muhammad Z. Influence of sulphur and nitrogen on growth, yield and quality of wheat crop grown in Peshawar region of Pakistan. J Global Inno Agric Social Scie. 2015;3(4):124-9.

40. DeRuiter J, Martin R. Management of nitrogen and sulphur fertilizers for improved bread wheat (Triticum aestivum L.) quality. N Zealand J Crop Horti Sci. 2001:29:287-99.

41. Sakal R, Sinha R, Sing A, Bhogal N, Ismail M. Influence of sulphur on yield and mineral nutrition of crops in maize-wheat sequence. J Indian Soc Soil Sci. 2000;48:325-9.

42. Randhawa PS, Arora CL. Phosphorus-sulfur interaction effects on dry matter yield and nutrient uptake by wheat. J Indian Soc Soil Sci. 2000:48:536-44. 
43. Tiwari KN, Upta BR. Sulphur for sustainable high yield agriculture in Uttar Pradesh. Indian J Fert. 2006;1:37-52.

44. Ogunsola KE, Adetunji MT. Effects of phosphorus and sulphur on dry matter yield of maize (Zea mays) in some soils at Abeokuta, Ogun state, Nigeria. J Tropical Agric Food Environ Ext. 2016;15(2):1-8.

45. Uddin MH, Rahman KM, Rahman MZ, Alam Z, Salam MA. Effect of phosphorus and sulphur on yield of Brri Dhan 57. J Environ Scie Nat Res. 2014;7:7-11.

46. Islam M, Mohsan S, Afzal S, Akmal SM, Khalid R. Phosphorus and sulfur application improves the chickpea productivity under rain fed conditions. Int Agric Biol. 2011;13:713-8.

47. Muhammad I, Muhammad JK, Amjad Al, Amanullah J, Sajida P. Effect of phosphorus and sulfur on the yield and nutrient uptake of maize. Int J Farm Allied Sci. 2015;4(3):244-52.
48. Ahmed EM. Impact of phosphorus and sulphur application on yield, phosphorus and micronutrients uptake by wheat plants. Assiut J Agric Scie. 2016;47(4):201-14.

49. Islam MN, Hoque S, Islam A. Effect of P $\times$ S interactions on nutrient concentration and yield of wheat, rice and mung bean. J Indian Soc Soil Sci. 2006;54(1):86-91.

50. Sandeep KY, Ghanshyam S, Rajeev K, Pradeep K, Brij M. Effect of phosphorus, sulphur and zinc on growth, yield and yield attributes of wheat (Triticum aestivum). Int J Curr Microbiol App Sci. 2017;6(8):2581-4.

\section{Publisher's Note}

Springer Nature remains neutral with regard to jurisdictional claims in published maps and institutional affiliations.
Ready to submit your research? Choose BMC and benefit from:

- fast, convenient online submission

- thorough peer review by experienced researchers in your field

- rapid publication on acceptance

- support for research data, including large and complex data types

- gold Open Access which fosters wider collaboration and increased citations

- maximum visibility for your research: over $100 \mathrm{M}$ website views per year

At BMC, research is always in progress.

Learn more biomedcentral.com/submissions 